\title{
ENGARUH PEMBELAJARAN BERBASIS STEM (SCIENCE, TECHNOLOGY, ENGINEERING, AND MATHEMATICS) PADA KONSEP TEKANAN HIDROSTATIS TERHADAP CAUSAL REASONING SISWA SMP
}

\author{
Dini Fitriani, Ida Kaniawati, Irma Rahma Suwarma \\ Prodi Pendidikan Fisika FMIPA UPI, Jl. Dr. Setiabudhi No. 229 Isola, Sukasari, Kota Bandung 40154 \\ Email: dinifitriani111994@gmail.com
}

\begin{abstract}
Abstrak
Fakta dilapangan menunjukan bahwa proses pembelajaran di kelas belum menciptakan aktivitas siswa dalam membuat prediksi, mengaitkan variabel satu sama lain, serta menganalisis hubungan materi dalam pengaplikasian di kehidupan nyata. Maka dari itu, dikembangkan penelitian tentang "Pembelajaran Berbasis STEM (Science, Technology, Engineering, and Mathematics) pada konsep Tekanan Hidrostatis. Penelitian ini dilakukan dengan tujuan untuk mengetahui pengaruh pembelajaran berbasis STEM terhadap peningkatan causal reasoning siswa pada konsep tekanan hidrostatis. Metode yang digunakan pada penelitian ini adalah pre experimental dengan one group pretest and posttest design. Penelitian dilakukan di salah satu SMP di kota Bandung Barat dengan jumlah partisipan dalam penelitian sebanyak 36 siswa dari siswa SMP kelas VIII. Data penelitian diambil dari hasil pretest dan posttest melalui tes scientific reasoning modifikasi bentuk pilihan ganda beralasan dan diolah menggunakan effect size (d) Cohen's untuk melihat pengaruh treatment terhadap peningkatan scientific reasoning. Dari hasil pengolahan dan analisis data, effect size yang terukur sebesar 1,89 masuk dalam kategori besar. Hal tersebut menunjukan bahwa pembelajaran berbasis STEM mampu memberikan pengaruh yang signifikan dalam melatihkan causal reasoning siswa.
\end{abstract}

Kata-kata kunci: Pembelajaran Berbasis STEM, Causal Reasoning. Abstract

\section{PENDAHULUAN}

Kualitas mutu pendidikan suatu bangsa dapat menentukan kemajumunduran suatu bangsa. salah satu cara untuk meningkatkan kualitas mutu pendidikan Indonesia adalah dengan mengembangkan dan melatih kemampuan penalaran ilmiah (scientific reasoning) siswa di sekolah.

Seperti yang telah dikatakan oleh Bao, et al. (2009) mengatakan bahwa pengembangan kemampuan penalaran ilmiah akan lebih memungkinkan siswa untuk menangani masalah yang baru dan merencanakan penyelidikan untuk menyelesaikan persoalan-persoalan sains, teknik, dan sosial di kehidupan nyata. Salah satu cara yang dapat dilakukan oleh guru untuk melatihkan kemampuan scientific reasoning siswa ialah dengan menerapkan pembelajaran berbasis STEM (Science, Technology, Engineering, and mathematics). Seperti sama halnya yang dipaparkan Han (2013) bahwa "Penting untuk menyelidiki bagaimana menerapkan program pendidikan STEM yang dapat membantu siswa mengembangkan pengetahuan konten STEM dan penalaran ilmiah". Selain itu, pembelajaran berbasis STEM mampu melatihkan kemampuan scientific reasoning, seperti yang dipaparkan Bao, et al. (2009, hlm.1) bahwa "Tujuan pengajaran di bidang pendidikan STEM 
termasuk mengembangkan konten pengetahuan dan mengembangkan kemampuan ilmiah yang umum. Salah satu kemampuan tersebut, penalaran ilmiah".

Pembelajaran IPA sebaiknya tidak dipisahkan dengan kehidupan nyata seperti yang telah dikatakan Bybee (2013) bahwa STEM merupakan pembelajaran terapan yang menggunakan pendekatan antar-ilmu (Science, Technology, Engineering, and mathematics) menerapkan dan mempraktikan konten dasar dari STEM pada situasi yang siswa hadapi/temukan dalam kehidupan nyata. Hal ini dapat diartikan bahwa pembelajaran berbasis STEM bukan pembelajaran yang hanya membicarkan ilmu pengatahuan alam saja, melainkan pembelajaran yang mengaitkan ilmu pengetahuan alam, teknologi, teknik, dan matematika serta mengkorelasikannya dengan kehidupan nyata.

Terdapat delapan tahap strategi pengajaran dan pembelajaran science dan engineering dikutip oleh Bybee (2011) yang diadopsi dari National Research Council (NRC).

Pada penelitian ini, peneliti memfokuskan variabel yang diukur dari scientific reasoning hanya dibatasi pada dimensi Penalaran kausal atau disebut causal reasoning. Causal reasoning merupakan penalaran dimana siswa mampu menentukan hubungan sebab akibat, mampu menghubungkan antara teori dengan fakta (dalam iStraAssessment, 2011). Pentingnya causal reasoning adalah seperti yang dikatakan Hung \& Jonassen (2006) bahwa kurangnya pemahaman konseptual dan kesulitan dalam memecahkan masalah dikarenakan kurangnya penalaran kausal. Selain itu penelitian dalam dimensi causal reasoning perlu dilakukan untuk melihat dukungan metode pengajaran yang digunakan dalam mendukung causal reasoning pada peserta didik (Jonasssen \& Ionas, 2006).

\section{METODE PENELITIAN}

Penelitian yang bertujuan melihat pengaruh pembelajaran berbasis STEM pada konsep tekanan hidrostatis terhadap causal reasoning siswa SMP ini menggunakan metode eksperimental preexperimental design. Seperti halnya yang dijelaskan Creswell, John W (2014, hlm.219). Dalam penelitian ini, peneliti menggunakan desain one group pretest-posttest design (Fraenkel dan Wallen, 2009, hlm. 265). Terdapat tiga tahap prosedur dalam penelitian ini, pertama-tama siswa diberikan pretest kemudian treatment dengan menerapkan pembelajaran berbasis STEM. Tahap terakhir berupa pemberian postest dengan instrumen yang sama. Penelitian dilakukan kepada 36 siswa kelas VIII dari SMPN 3 Lembang di kota Bandung Barat. Sampel yang dipilih satu kelas VIII secara random dari keseluruhan populasi di SMP tersebut (Jhon W Creswell, 2014, hlm.204). instrumen penelitian yang digunakan untuk mengumpulkan data dalam penelitan ini berupa keterlaksanaan pembelajaram berbasis STEM dengan tes scientific reasoning pada dimensi causal reasoning dengan konten hukum hidrostati sebanyak 4 butir soal yang sebelumnya sudah diuji validitas dan reabilitas. Berikut jenis data, instrumen dan waktu pengumpulan data pada tabel di bawah ini:

Tabel 2.1 Jenis Data, Instrumen serta Waktu Pengumpulan Data

\begin{tabular}{ccc}
\hline Jenis Data & Instrumen & Waktu Pengambilan Data \\
\hline Causal Reasoning & Tes scientific reasoning dimensi causal & Sebelum dan setelah \\
Siswa & reasoning & diberikan treatment \\
\hline
\end{tabular}

Analisis data penelitian instrumen tes scientific reasoning dimensi causal reasoning menggunakan persamaan Cohen's effect size untuk mengukur tingkat kemampuan causal reasoning siswa setelah dampak dari pembelajaran berbasis STEM dengan formula sebagai berikut (Dunst, Carl $\mathrm{J}$ et al, 2004, hlm.7-8)

$$
d=\frac{\left(M_{I}-M_{B}\right)}{\sqrt{S D_{B}^{2}+S D_{I}^{2} / 2}}
$$




\section{keterangan :}

$$
\begin{array}{cl}
d & : \text { effect size } \\
\mathrm{M}_{\mathrm{I}} & \text { : rata-rata skor posttest } \\
\mathrm{M}_{\mathrm{B}} & \text { : rata-rata skor pretest } \\
\mathrm{SD}_{\mathrm{B}} & : \text { standar deviasi posttest } \\
\mathrm{SD}_{\mathrm{I}} & \text { : standar deviasi pretest }
\end{array}
$$

Persamaan ini dipakai bila korelasi antara pretest dan posttest bernilai kecil, dengan korelasi yang didapat dalam penelitian sebesar 0,34 masuk dalam kategori kecil. Melalui perhitungan effect size, jika signifikansi angka yang terukur kurang dari 0,50 maka H0 ditolak. Dapat dikatakan bahwa terdapat pengaruh antara pembelajaran berbasis STEM terhadap kemampuan peningkatan causal reasoning siswa.

\section{HASIL DAN PEMBAHASAN}

Penelitian yang menggunakan treatment pembelajaran berbasis STEM ini menggunakan rancangan science and engineering dalam proses pembelajaran sebanyak 8 tahap dari National Research Council (NRC) (dikutip oleh Bybee, 2011).

1. Mengajukan pertanyaan dan mendefinisikan masalah.

2. Mengembangkan dan menggunakan model atau contoh

3. Merencanakan dan melakukan penyelidikan

4. Analisis dan interpretasi data

5. Menggunakan cara berpikir matemati dan komputasional

6. Mengembangkan penjelasan dan mendesain solusi

7. Terlibat dalam argumentasi dan bukti

8. Memperoleh, mengevaluasi, dan mengkomunikasikan informasi

Dari delapan tahap tersebut, causal reasoning dilatihkan pada tahap mengajukan pertanyaan dan mendefinisikan masalah serta analisis dan interpretasi data. Berikut tabel proses pembelajaran berbasis STEM dalam melatihkan causal reasoning siswa pada konsep tekanan hidrostatis.

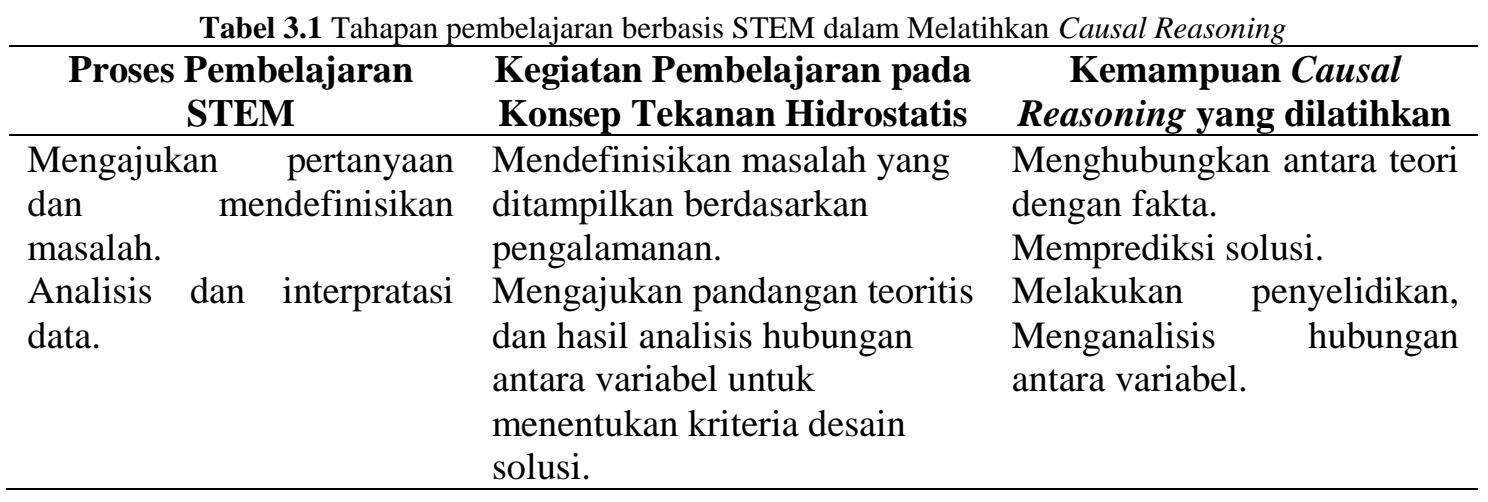

Berikut hasil pengolahan nilai setiap item soal causal reasoning : 


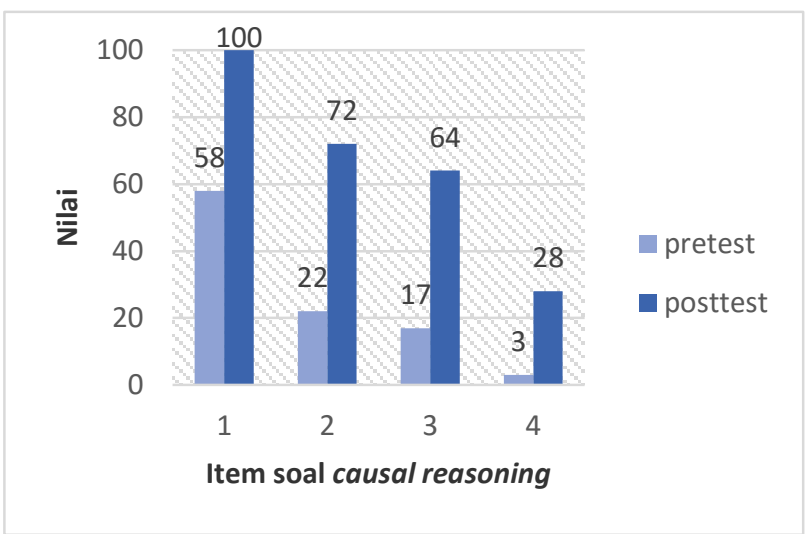

Gambar 3.1 Nilai setiap Item Soal Causal Reasoning

Sedangkan hasil pengolahan data instrumen berupa tes scientific reasoning pada dimensi causal reasoning menggunakan effect size dapat dilihat pada tabel 3.2 :

Tabel 3.2 Hasil Analisis Treatment terhadap Causal Reasoning Siswa

\begin{tabular}{ccc}
\hline Signifikasi & Kategori & Keterangan \\
\hline 1,89 & Besar/Large effect & $\mathrm{H}_{1}$ diterima \\
\hline
\end{tabular}

\section{HASIL DAN PEMBAHASAN}

Treatment yang diberikan kepada siswa berupa pembelajaran berbasis STEM pasti memberikan dampak pada kemampuan causal reasoning siswa, , hal ini dibuktikan dengan hasil nilai yang diperoleh dari pretest dan posttest serta signifikansi effect size yang diperoleh masuk dalam kategori besar.

Causal reasoning dikenal sebagai Sedangkan hasil pengolahan data instrumen berupa tes scientific reasoning pada dimensi causal reasoning menggunakan effect size dapat dilihat pada tabel 3.2 :

Tabel 3.2 Hasil Analisis Treatment terhadap Causal Reasoning Siswa

\begin{tabular}{ccc}
\hline Signifikasi & Kategori & Keterangan \\
\hline 1,89 & Besar/Large effect & $\mathrm{H}_{1}$ diterima \\
\hline
\end{tabular}

Treatment yang diberikan kepada siswa berupa pembelajaran berbasis STEM pasti memberikan dampak pada kemampuan causal reasoning siswa, , hal ini dibuktikan dengan hasil nilai yang diperoleh dari pretest dan posttest serta signifikansi effect size yang diperoleh masuk dalam kategori besar.

Causal reasoning dikenal sebagai Penalaran yang menghubungkan antara sebab dan akibat variabel satu terhadap variabel yang lainnya, menghubungkan antara teori dengan fakta yang ditampilkan (iStarAssessment, 2011). Causal reasoning merupakan salah satu kemampuan yang paling dasar dan penting dalam proses kognitif dalam pembentukan pengetahuan dan pemecahan masalah (Jonasssen \& Ionas, 2006). Mengacu pada kemampuan causal reasoning yang dilatihkan pada proses pembelajaran berbasis STEM, causal reasoning diperlukan dalam membuat prediksi, menggambarkan implikasi dan kesimpulan, serta menjelaskan fenomena (Jonasssen \& Ionas, 2006).

Dari hasil pengolahan nilai pretest dan posttest soal causal reasoning gambar 3.1, soal nomor 2 berada diurutan pertama yang memiliki rata-rata nilai terbesar dibandingkan dengan nomor soal lainnya. Sedangkan soal nomor 4 memiliki rata-rata nilai terendah dibandingkan dengan nomol soal lainnya. Indikator soal nomor 2 ialah menyelidiki kaitan antara variable satu dengan variabel yang lainnya. Soal nomor 1 dan 3 tergolong sedang dilihat dari rata-rata nilai yang ditampikan dengan indikator soal nomor 1 ialah menentukan hubungan antara pengaruh variabel satu terhadap variabel 
lainnya dan indikator soal nomor 3 ialah menjelaskan kaitan antara variabel. Sedangkan indikator pada soal nomor 4 ialah merancang desain bendungan menggunakan konsep tekanan hidrostatis dan indikator ini lebih kompleks dibandingkan indikator soal causal reasoning lainnya

Pada pembelajaran yang telah dilakukan pada tahap mengajukan pertanyaan dan mendefinisikan masalah, siswa dilatihkan dalam menghubungkan kaitan sebab akibat antara variabel satu dengan variabel lainnya di setiap pertemuannya. Sedangkan pada tahap menganalisis dan menafsirkan data, siswa dilatihkan dalam menganalisis penyebab permasalahan dan menafsirkan hubungna antara variabel untuk dapat memberikan solusi, dan tahapan ini hanya dilakukan dalam satu pertemuan saja. Oleh karena itu pengaruh besarnya nilai soal causal reasoning untuk nomor 1, 2, dan 3 dikarenakan selama proses pembelajaran siswa dilatihkan dalam menghubungkan, menyelidiki kaitan, serta mampu menjelaskan kaitan antara variabel antara teori dengan fakta yang ditampilkan, sehingga hal ini menjadi dampak dari besarnya nilai yang ditampilkan. Sedangkan pada soal nomor 4, siswa tidak hanya menghubungkan sebab akibat antara teori dengan fakta yang terlihat, akan tetapi siswa diminta untuk memberikan rancangan solusi dari konsep yang telah didapatnya pada proses pembelajaran. Oleh sebab itu, nilai yang ditampilkan lebih kecil dibandingkan nilai pada soal lainnya. Dalam melatihkan kemampuan causal reasoning pada tahap menganalisis dan menafsirkan data, dapat dikatakan bahwa melatihkan causal reasoning kurang terlaksana dengan maksimal, hal ini dilihat dari nilai yang rendah pada soal nomor 4 yang berkorelasi dengan tahap ini.

Faktor luar yang menjadikan tahap menganalisis dan menafsirkan data kurang terlaksana dengan baik, hal ini dikarenakan pembelajaran pada konsep tekanan hidrostatis hanya dilakukan selama dua kali pertemuan, dan tahap menganalisis dan menafsikran data hanya dilatihkan pada pertemuan kedua saja. Selain ini, menejemen waktu yang diberikan terbatas pada tahapan ini membuat siswa kurang menghayati pembelajaran pada tahapan ini. Faktor-faktor tersebut memungkinkan pembelajaran berbasis STEM dalam melatihkan causal reasoning siswa kurang terlaksana dengan maksimal.

Berdasarkan paparan diatas, maka masih diperlukan penelitian lebih lanjut terkait pembelajaran IPA berbasis STEM terhadap kemampuan causal reasoning dan pada dimensi lainnya. Secara keseluruhan, pembelajaran berbasis STEM pada topik bahasan konsep tekanan hidrostatis ini mampu mempengaruhi peningkatan scientific reasoning pada dimensi causal reasoning. Pengaturan waktu sangat diperlukan dalam proses pembelajaran selanjutnya, sehingga dapat memberikan data secara keseluruhan dampak pembelajaran berbasis STEM terhadap scientific reasoning siswa.

\section{SIMPULAN}

Dari hasil yang telah dipaparkan, dapat disimpulkan bahwa pembelajaran berbasis STEM (Science, Technology, Engineering, and Mathematics) memberikan kontribusi besar dalam mempengaruhi peningkatan kemampuan causal reasoning siswa SMP pada konsep tekanan hidrostatis.. Dengan demikian, pembelajaran berbasis STEM dapat menjadi rujukan dalam melatihkan kemampuan causal reasoning siswa. Namum demikian, perlunya penelitian lebih lanjut terkait kendala yang muncul dalam keterlaksanaan proses pembelajaran ini. Salah satu saran untuk penelitian selanjutnya ialah pembelajaran berbasis STEM dengan menggunakan alam sebagai media dalam memahami konsep fisika secara holistik/menyelururuh (Suwarma, Irma et al., 2015).

\section{REFERENSI}

[1] Boa, Lei, et al, "Learning and Scientific Reasoning," AAAS, vol. 323, pp. 586587, Jan 2009.

[2] Bybee, W Rodger, "Scientific and Engineering Practices in K-12 Classrooms. Understanding A Framework for K-12 Science Education," U.S. Patent, NSTA. December 2011.

[3] Bybee, W Rodger, "The Case for STEM Education Challenges and Oppartunities" in NSTA press. Amerika: 2013. 
[4] Creswell, John W, "Research Design. Qualitative, Quantitative, and Mixed methods Approaches" Sage. California:. 2014.

[5] Dunst, Carl J et al, "Guildelines for Calculating Effect Sizes for Practice-Based Research Syntheses," centerscope, vol. 3, no. 1, pp. 1-9, November 2004.

[6] Fraenkel, Jack R. \& Wallen, Norman E, "How to Design and Evaluate Research in Education," McGraw-Hill Companies. New York: 2009.

[7] iSTARAssessment. (2011 April 11). Networks Causal Reasoning. [Online]. Available http://www.istarassessment.org/srdims/causal-reasoning-2/

[8] Jonasssen, David H. \& Ionas, Ioan Gelu, "Designing effective supports for causal reasoning," (in Columbia), Springer, vol. 56, no. 3, pp. 287-308, June 2008. 